\title{
Teaching NeuroImages: Stroke presenting with isolated superior branch of cranial nerve III palsy
}

Gaurav Kapoor, DO, Yash D. Shah, MD, MPH, and Richard Libman, MD

Neurology ${ }^{\circledR}$ 2020;94:e562-e563. doi:10.1212/WNL.0000000000008894

Correspondence

Dr. Libman

rlibman@northwell.edu
Figure MRI brain and photographs of the patient
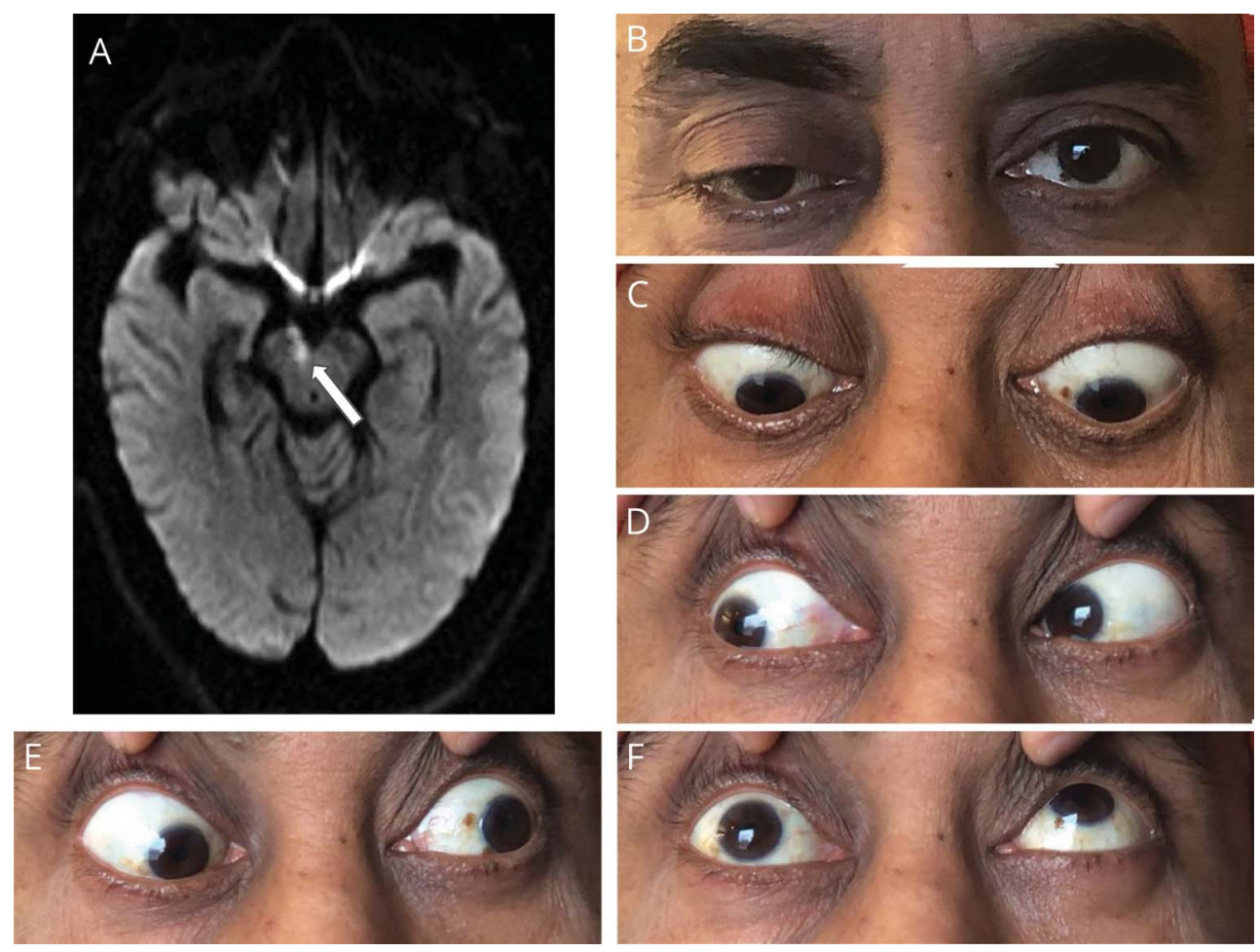

(A) MRI brain noncontrast reveals abnormal T2 prolongation with mild restricted diffusion seen involving the medial aspect of the right cerebral peduncle. (B-E) Extraocular movements. (B) Right ptosis. (C-E) Normal infraduction, abduction, and adduction bilateral. (F) Impaired supraduction of right eye on upgaze.

A 53-year-old man presented with diplopia. On examination, he had mild to moderate right ptosis and limited supraduction in the right eye with no abnormalities of adduction, abduction, infraduction, or pupillary reactivity (figure, B-E). MRI brain revealed restricted diffusion consistent with acute infarction involving the medial aspect of the right cerebral peduncle (figure, A).

In the orbit, the third nerve divides into superior (supplying superior rectus and levator palpebrae superioris) and inferior (supplying medial and inferior recti, inferior oblique and ciliary ganglion) divisions. This case supports the consistency of third nerve structural organization within the midbrain, a rare manifestation of partial third nerve palsy caused by a stroke. ${ }^{1,2}$

\section{MORE ONLINE}

$\rightarrow$ Teaching slides

links.lww.com/WNL/

B40

\section{Study funding}

No target funding reported.

From the Department of Neurology (G.K., R.L.) and Department of Pediatric Neurology, Cohens Children's Hospital and Medical Center (Y.D.S.), Long Island Jewish Medical Center, Glen Oaks; and Department of Neurology (R.L.), Zucker School of Medicine at Hofstra/Northwell and North Shore University Hospital, Manhasset, NY.

Go to Neurology.org/N for full disclosures. Funding information and disclosures deemed relevant by the authors, if any, are provided at the end of the article. 


\section{Disclosure}

The authors report no disclosures relevant to the manuscript. Go to Neurology.org/N for full disclosures.

\section{References}

1. Saeki N, Murai H, Mine S, Yamaura A. Fascicular arrangement within the oculomotor nerve MRI analysis of a midbrain infarct. J Clin Neurosci 2000;7:268-270.

2. Purvin V. Isolated fascicular third nerve palsy. J Neuroophthalmol 2010;30:263-265.

\section{Appendix Authors}

\begin{tabular}{llll}
\hline Name & Location & Role & Contribution \\
\hline $\begin{array}{l}\text { Gaurav } \\
\text { Kapoor, } \\
\text { Do }\end{array}$ & $\begin{array}{l}\text { Long Island } \\
\text { Jewish } \\
\text { Medical } \\
\text { Center }\end{array}$ & Author & $\begin{array}{l}\text { Major role in the acquisition } \\
\text { and interpretation of data, } \\
\text { drafted the manuscript for } \\
\text { intellectual content }\end{array}$ \\
\hline $\begin{array}{l}\text { Yash D. } \\
\text { Shah, } \\
\text { MD, MPH }\end{array}$ & $\begin{array}{l}\text { Cohen } \\
\text { Children's }\end{array}$ & Author & $\begin{array}{l}\text { Major role in the acquisition } \\
\text { and interpretation of data, } \\
\text { drafted the manuscript for } \\
\text { intellectual content }\end{array}$ \\
$\begin{array}{l}\text { Center } \\
\text { Richard } \\
\text { Libman, } \\
\text { MD }\end{array}$ & $\begin{array}{l}\text { Long Island } \\
\text { Jewish }\end{array}$ & Author & $\begin{array}{l}\text { Major role in the interpretation } \\
\text { of data, revised manuscript for } \\
\text { intellectual content }\end{array}$ \\
& Center & & \\
\hline
\end{tabular}




\section{Neurology}

\section{Teaching NeuroImages: Stroke presenting with isolated superior branch of cranial nerve III palsy}

Gaurav Kapoor, Yash D. Shah and Richard Libman

Neurology 2020;94;e562-e563 Published Online before print January 20, 2020

DOI 10.1212/WNL.0000000000008894

This information is current as of January 20, 2020

\section{Updated Information \&} Services

References

Subspecialty Collections

Permissions \& Licensing

Reprints including high resolution figures, can be found at: http://n.neurology.org/content/94/5/e562.full

This article cites 2 articles, 0 of which you can access for free at: http://n.neurology.org/content/94/5/e562.full\#ref-list-1

This article, along with others on similar topics, appears in the following collection(s):

\section{All Cerebrovascular disease/Stroke}

http://n.neurology.org/cgi/collection/all_cerebrovascular_disease_strok e

Information about reproducing this article in parts (figures,tables) or in its entirety can be found online at:

http://www.neurology.org/about/about_the_journal\#permissions

Information about ordering reprints can be found online:

http://n.neurology.org/subscribers/advertise

Neurology ${ }^{\circledR}$ is the official journal of the American Academy of Neurology. Published continuously since 1951, it is now a weekly with 48 issues per year. Copyright @ 2020 American Academy of Neurology. All rights reserved. Print ISSN: 0028-3878. Online ISSN: 1526-632X.

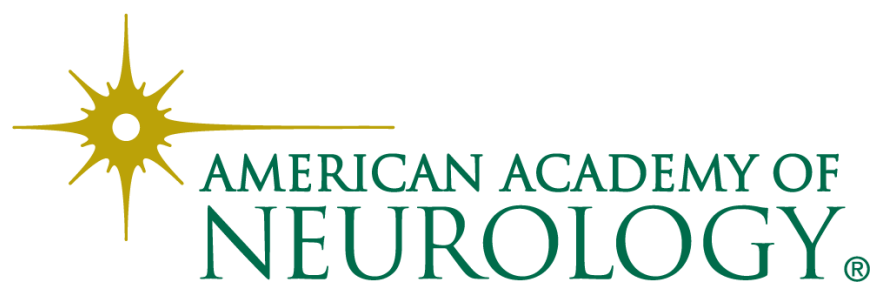

